\title{
Role of Local Biofertilizer in Enhancing the Oxidative Stress Defence Systems of Date Palm Seedling (Phoenix dactylifera) against Abiotic Stress
}

\author{
Oumaima Harkousse $\mathbb{D}^{\mathrm{D}},{ }^{1,2}$ Afafe Slimani, ${ }^{1,2}$ Issam Jadrane, ${ }^{3}$ Mohamed Aitboulahsen $\mathbb{D}^{4}$, \\ Mouaad Amine Mazri $\mathbb{D}^{5}{ }^{5}$ Abdelmjid Zouahri, ${ }^{6}$ Lahcen Ouahmane $\mathbb{D}^{3},{ }^{3}$ Tayeb Koussa $\mathbb{D}^{2}$, \\ and Mohamed Najib Al Feddy ${ }^{1}{ }^{1}$
}

\author{
${ }^{1}$ National Institute of Agronomic Research, Plant Protection Unit, Laboratory of Phyto-Bacteriology, Marrakech, Morocco \\ ${ }^{2}$ Laboratory of Plant Biotechnology, Ecology and Ecosystem Exploitation, Department of Biology, Faculty of Sciences, \\ El Jadida, Morocco \\ ${ }^{3}$ Cadi Ayyad University, Laboratory of Microbial Biotechnologies, Agro-sciences and Environment, Marrakesh, Morocco \\ ${ }^{4}$ Department of Biology, Polydisciplinary Faculty of Larache, Abdelmalek Essaâdi University, B.P. 745, Larache, \\ Tétouan, Morocco \\ ${ }^{5}$ National Institute of Agronomic Research, UR Agro-Biotechnology, Laboratory of Plant Biotechnology, Marrakech, Morocco \\ ${ }^{6}$ National Institute of Agronomic Research, UR Environment, and Conservation of Natural Resources, Rabat, Morocco
}

Correspondence should be addressed to Mohamed Aitboulahsen; maitboulahsen@uae.ac.ma

Received 19 December 2020; Accepted 5 May 2021; Published 18 May 2021

Academic Editor: Maman Turjaman

Copyright (C) 2021 Oumaima Harkousse et al. This is an open access article distributed under the Creative Commons Attribution License, which permits unrestricted use, distribution, and reproduction in any medium, provided the original work is properly cited.

\begin{abstract}
Among the abiotic stresses, drought is the first environmental stress responsible for a decrease in agricultural production worldwide; it affects plants in various ways, including slowing down plant growth and disrupting its general physiology. Arbuscular mycorrhizal symbiosis and plant growth-promoting rhizobacteria (PGPR) are considered to be the bioameliorators of the plant's resistance to water stress. The present study investigated the effects of inoculation with arbuscular mycorrhizal fungi (AMF) and PGPR on the water status and antioxidant enzyme activities of date palm seedlings grown under water stress conditions. The parameters related to the plant's water status were significantly $(p<0.05)$ higher in the plants treated with mycorrhizae and mycorrhizae + bacteria compared with their respective controls, especially under water stress conditions. The maximum proline content was obtained in plants inoculated with the AMF species and PGPR (combined) under severe water stress conditions reaching a value of $2.588 \pm 0.034$ in $25 \%$ field capacity, compared with $0.978 \pm 0.024$ for the control. In addition, the inoculated seedlings showed notably lower activities of superoxide dismutase (SOD), catalase (CAT), peroxidase (POX), and glutathione S-transferase (GST) in response to severe water stress compared with nonmycorrhizal seedling. Overall, the arbuscular mycorrhizal symbiosis and PGPR bacteria inoculation could be promising methods to enhance date palm resistance against oxidative stress.
\end{abstract}

\section{Introduction}

Agriculture production decreases globally mainly due to biotic and abiotic stresses. Abiotic stresses reduce the growth and development of plants at biochemical and molecular levels and cause immense crop loss in agricultural production [1,2]. This environmental stress poses a major challenge in our quest for sustainable food production as it reduces the potential yields as high as $70 \%$ in crop plants [3]. Overall, abiotic stress often results in several morphological, physiological, biochemical, and molecular changes that adversely affect plant growth, development, and productivity. Among these stresses, drought is the first environmental stress responsible for a decrease in agricultural 
production worldwide; it affects plants in various ways, including slowing down plant growth, disrupting the membrane integrity of vital cellular organelles such as chloroplasts, depriving photosynthesis, and creating an imbalance in osmoregulation yield. Salinity is the second most prevalent soil problem after drought $[4,5]$. It should also be noted that nearly, all of these abiotic stresses result in oxidative stress and involve reactive oxygen species (ROS) formation in plant cells [1]. Under normal conditions, antioxidant enzymes keep the production of ROS in cells at low levels. This balance can be disturbed by the loss of antioxidants or excessive concentration of ROS, resulting in oxidative stress and causing ultimate damage to cellular macromolecules and membranes and increased lipid peroxidation $[6,7]$.

Nevertheless, in many cases, the production of activated oxygen in plants exceeds their ability to detoxify it [8]. Therefore, sometimes, most plants possess an additional mechanism that helps them to tolerate stress, which consists of an association with the microbial population of their rhizosphere surrounding that can help them to survive and ameliorate their productivity [9]. The microorganisms can be present in the rhizosphere, root tissue, and/or a special root structure called a nodule, and they generally include bacteria, algae, fungi, protozoa, and actinomycetes [9]. Different types of bacteria have a significant effect on plant growth and are known as plant growth-promoting rhizobacteria (PGPR). They play an important role in increasing plant growth and development through some direct and indirect mechanisms such as plant growth regulators and organic acids as well as protection through enzymes, under both nonstress and stress conditions [10-12]. Generally, PGPR bacteria can increase plant growth by increasing the nutrient's availability in the rhizosphere and also enhance the production of plant hormones, such as IAA [13]. They can also stimulate plant growth and development throughout the production of substances such as exopolysaccharides and rhizobitoxin that allow the plants to withstand abiotic stress conditions $[11,14]$.

In addition to the bacterial population present in the rhizosphere, fungi also represent a significant portion of soil rhizosphere microflora and play an important role in plant growth. The symbiotic association generated by fungi (mycorrhizae) with plant roots increases the root surface area and thus allows the plant to absorb water and nutrients more efficiently from large soil volume. This obligated mycorrhizal association not only increases the nutrient and water availability but also protects the plant from a variety of abiotic stresses [15-18].

Some mechanisms used by arbuscular mycorrhizal fungi (AMF) under certain conditions can explain the growth promotion due to this association, which includes the production of metabolites such as amino acids, vitamins, phytohormones, and/or processes of solubilization and mineralization [19]. It is also well documented that AMF influence the expression of several antioxidant enzymes that protect plants from reactive oxygen species generated under stress conditions [20,21]. While supplying plants with nutritional and structural benefits, they also provide other benefits to them including production/accumulation of secondary metabolites for osmotic adjustment under osmotic stress, improved nitrogen fixation, enhanced photosynthesis rate, and increased resistance against biotic and abiotic stresses. Many researchers have reported that AMF can improve plant's tolerance to heavy metals, drought, and salinity and also protect plants from pathogens [22-26].

Date palm is one of the most important members of the Palmaceae family and one of the oldest fruit crops grown in the arid regions [27]. It has long been one of the major fruit crops for many arid and semiarid populations because of its high productivity, the high nutrient value of its fruits, and its adaptation to conditions of the Saharan regions. It has a very ancient history and it is still a key food supply for this population. During the past three centuries, dates were also introduced to new production areas in Australia, India, Pakistan, Mexico, southern Africa, South America, and the United States [27]. Dates are the main income source and staple food for local populations in many countries in which they are cultivated and have played significant roles in the economy, society, and the environment of those countries [28]. Moroccan date palm groves occupy a surface area of more than 48,000 ha with a population of 4.8 million trees; they are composed of about $55.6 \%$ seed-derived seedlings representing about 2.5 million trees, each of which is genetically different [29]. However, these groves are facing a tremendous risk of disappearing with the permanent stress due to the destructive "Bayoud" disease caused by the soil fungus (Fusarium oxysporum f. sp. albedinis), one of the known diseases in the world that is difficult to control, as well as the prolonged drought and traditional water management in the country. In order to combat "Bayoud" disease, the National Institute of Agronomic Research (INRA) has developed resistant cultivars for date palm trees: "Najda" cultivar, with good fruit quality and resistance to the disease [29]. Despite its good performances with the biotic stress, this cultivar is still very affected by drought stress and in need of more strategies against this abiotic stress.

In a previous study, we have demonstrated the effect of AMF and PGPR bacteria symbiosis on the growth parameters of date palm "Najda" cultivar under drought stress. The present study focuses on the biochemical activity and enzymatic responses of this cultivar under drought stress conditions. While featuring the role of the AMF and PGPR bacteria, symbiosis plays a role in the antioxidant response. To our knowledge, no study has been conducted for date palm "Najda" cultivar under water stress conditions. Plant cells produce different antioxidant enzymes such as catalase (CAT), peroxides (POX), superoxide dismutase (SOD), and glutathione S-transferase (GST) that scavenge the reactive free radicals [30]. In this paper, we studied the effect of inoculation of drought-tolerant plant growth-promoting bacteria Bacillus S48 isolated originally from arid rhizosphere and a complex of 28 different species of AMF isolated from the rhizosphere of a Zagora palm grove on the tolerance of date palm "Najda" cultivar to drought stress in terms of the biochemical status of the plants. 


\section{Materials and Methods}

\subsection{Plant, Soil, and Microorganisms}

2.1.1. Arbuscular Mycorrhizal Fungi Spores. Soil samples containing root fragments were taken near the rhizosphere of a palm grove in Zagora, located in the experimental domains of INRA (Regional Centre for Agronomic Research of Errachidia, Experimental Domain of Zagora), at a depth of approximately $10 \mathrm{~cm}$ to $40 \mathrm{~cm}$, with 3 samples for each type of rhizospheric soil.

2.1.2. Trap Culture. Trapping is highly necessary to obtain many healthy spores of colonizing fungi for identification and as inoculum. The trap cultures were prepared as follows: the plant's debris and shoots were removed from the soil samples collected, and the roots fragments were cut into small fragments and mixed with the associated soil. After that, the blend was mixed in $1: 1(\mathrm{v} / \mathrm{v})$ ratio with autoclaved soil and then transferred into plastic pots $(13 \times 09 \mathrm{~cm})$ with barley seeds (80-100 seeds/pot). Barley (Hordeum vulgare L.) was used as a host plant for the trapping cultures, and the pots were kept in a greenhouse for at least four months before being used.

2.1.3. PGPR Bacteria. The bacterial strain was isolated from an arid soil in the Saada experimental domains of INRA, Marrakech. It was selected for its beneficial activities to plant growth and health, more precisely for its positive effect on two Moroccan wheat varieties (Triticum durum Desf.) in a previous study conducted in vitro by Chrouqi et al. [31] in the same laboratory.

2.1.4. Mycorrhizal Inoculum Multiplication. The MF inoculum cannot be produced independently from the plant. Mycorrhizal fungi spores were isolated from different soils and have to be trapped and multiplicated on a host plant. Thereby, the AMF inoculation was supplied in the form of barley root segments infected by the above AM fungi complex from the morphological identification. The parameters of barley root infection were calculated after 4 months of culture using the technique stated by Trouvelot et al. [32]. The frequency of infection was approximately maintained at $80 \%$ for the barley roots; then they were surface-disinfected for $10 \mathrm{~min}$, rinsed with sterile distilled water thrice for $10 \mathrm{~min}$, and cut into $1-2 \mathrm{~mm}$ long fragments to be used as an inoculum based on the method suggested by Strullu et al. [33].

\subsection{Plant Growth Conditions}

\subsubsection{Mycorrhizal Inoculation and Growth Conditions.} The current experiment was conducted at the National Institute of Agronomic Research, Plant Protection Unit, Laboratory of Phyto-Bacteriology, Marrakech, during 8 months of growth in a greenhouse. Seedlings generated from "Najda" seeds were grown in plastic pots $(15 \times 14 \mathrm{~cm})$ filled with $2 \mathrm{~kg}$ of a mixture of sterile sand and peat $(2: 1 \mathrm{v} / \mathrm{v})$ under total conditions of $16 \mathrm{~h}$ light, $60-70 \%$ relative humidity, and $25-30^{\circ} \mathrm{C}$ temperature. The plants were divided into four major groups: control plants $(\mathrm{C})$, plants inoculated with AMF (M), plants inoculated with AMF + PGPR bacteria $(\mathrm{M}+\mathrm{B})$, and plants inoculated with PGPR bacteria only (B), with 10 plants in each treatment. Two grams of fresh weight of barley root fragments was applied to the plant roots as an inoculum. After 2 months of growth, the bacterial suspension was added to the $\mathrm{M}+\mathrm{B}$ and $\mathrm{B}$ treatments. The control plants were grown under the same conditions, without either the barley root fragments or the bacterial suspension.

\subsubsection{Bacterial Inoculation. The bacterium Bacillus genus} was extracted from the wheat rhizosphere grown in INRA's Saâda experimental domain, Marrakech. This bacterium was found to be the most effective PGPR strain with different multiple plant growth-promoting activities as described by Chrouqi et al. [31]. Bacterial suspensions were prepared as specified by Mayak et al. [34]. In summary, one bacterial colony was grown on a solid DF [35] medium containing ACC (1-aminocyclopropane-1-carboxylic acid) as a pure source of nitrogen, then inoculated to the YT medium, and finally incubated for $24 \mathrm{~h}$ with extensive shaking, approximately $250 \mathrm{rpm}$, for proper aeration. The bacterial cells were pelleted by centrifugation at 5,000x g for $10 \mathrm{~min}$ and then resuspended in distilled water. This was repeated twice to adjust the bacterial concentration at 1.0 absorbance unit at $600 \mathrm{~nm}$. The latter suspension was used to irrigate plants as indicated by Mayak et al. [34].

2.2.3. Water Stress Application. The date palm plantation was conducted in plastic three liter pots, fitted with a drainage system to remove the excess water, which allows determination of the field capacity (FC) of the soil [36]. Tobar et al. [36] explained the technique for the water stress application. W1 is the first weight of the pot full of dry soil. The same pot was then irrigated to saturation and left to drain under gravity until it reaches a steady weight of W2. The difference between the two weights (W2 - W1) matches the volume needed to obtain $100 \%$ FC of the soil used $(100 \%$ FC). Following this equation (1): (0.75 or 0.50 or $0.25) \times(\mathrm{W} 2-\mathrm{W} 1)$, the volume required for obtaining the weights of the buckets at $75 \%, 50 \%$, and $25 \%$ FC ( W3, W4, and W5) was determined, respectively. All through the experiment, pots were brought back to the weight corresponding to the water treatments imposed (100\%, 75\%, 50\%, or $25 \%$ FC) by successive weighing and irrigation. During the experiment, the pots were weighed twice a day in a balance of $70.041 \mathrm{M}, 0.1-5 \mathrm{~g}$ accuracy, and $30 \mathrm{~kg}$ weighing capacity, and the lost water was replaced. For each experimental treatment, four water regimes were applied $(100 \%$, $75 \%, 50 \%$, and $25 \%$ FC) with 10 plants in each treatment.

2.3. Determination of AMF Root Colonization. A part of the roots from the lateral root system is properly rinsed from soil 
remains, then cleaned using $10 \% \mathrm{KOH}$ at $90^{\circ} \mathrm{C}$ for $30 \mathrm{~min}$, acidified afterward with $1 \% \mathrm{HCl}$ for $10 \mathrm{~min}$, and finely stained with trypan blue at $90^{\circ} \mathrm{C}$ for $20 \mathrm{~min}$ as described by Phillips and Hayman [37]. The evaluation of the mycorrhization parameters was conducted for 30 root fragments of $1.0 \mathrm{~cm}$ in length using a Zeiss Axioskop 40 microscope at 40-100x magnification, according to Trouvelot et al. [32]. Two mycorrhizal parameters, the AMF infection frequency $(\mathrm{Fa} \%)$ and the AMF infection intensity (Ma \%), were calculated, as follows:

$$
\begin{aligned}
& \operatorname{AMF} \text { infection frequency }(\mathrm{Fa} \%)=\frac{\text { infected root segments }}{\text { total root segments }} \times 100, \\
& \operatorname{AMF} \text { infection intensity }(\mathrm{Ma} \%)=\frac{(95 n 5+70 n 4+30 n 3+5 n 2+n 1)}{\text { total root segments }},
\end{aligned}
$$

where $n 5$ is the root number with infection level of five (infection rate, $90-100 \%$ ); $n 4$ is the root number at level four (infection rate, $50-90 \%$ ); $n 3$ is the root number at level three (infection rate, $10-50 \%$ ); $n 2$ is the root number at infection level two (infection rate, $1-10 \%$ ); and $n 1$ is the root number at level one (infection rate, $0-1 \%$ ).

2.4. Measurement of Plant Growth Parameter. These measurements were carried out in the laboratory in the same way and under the same conditions. The plants were harvested after 32 weeks of growth, before drying the leaves at $105^{\circ} \mathrm{C}$ for $24 \mathrm{~h}$ to measure dry shoot weight (DW), and the fresh shoot weight $(\mathrm{FW})$ was measured to calculate the parameters related to the plant's water status.

2.5. Estimation of Relative Water Content. The relative water content estimation stated by Boyer [38] is a reliable indicator of the water balance state of the plants and considers not only the differences in the amount of water present in the tissues but also the changes in their capacity to absorb water during the tissue saturation experimental stage. The fresh leaf tissues were weighed to get the fresh weight (FW) before being placed in Petri dishes with water and incubated at room temperature for $24 \mathrm{~h}$. The tissues were later taken out, blotted dry, and weighed to get the turgid weight (TW). Subsequently, the samples were dried at $80^{\circ} \mathrm{C}$ for $24 \mathrm{~h}$ and weighed again to obtain the dry weight (DW).

RWC (\%) expresses the water content in the sample after harvest at a given time as related to the water content at full turgor (TW):

$$
\operatorname{RWC}(\%)=\frac{(F W-D W) \times 100}{(T W-D W)} .
$$

2.6. Determination of Membrane Permeability. Plant cell membranes play an important role in cell functioning, and they are made of a lipid bilayer with intrinsic or extrinsic proteins. In the event of stress, these membranes will undergo denaturation, which will alter their integrity. Leaf membrane permeability was measured by electric conductivity (EC) as described by Yan et al. [39]. Five discs from a leaf of each sample were removed with a cookie cutter and rinsed in a Petri dish containing distilled water. The discs were then placed in a beaker or tube containing $10 \mathrm{ml}$ of distilled water. The leaf samples were immersed at $30^{\circ} \mathrm{C}$ for 3 hours, and then the conductivity of the solution was measured for the first time with a previously calibrated conductimeter (C1). Then the conductivity was measured for a second time (C2) after placing the sample in a boiling water bath for 20 minutes and then cooled to room temperature. The percentage of electrolyte leakage was calculated as follows:

$$
\mathrm{EC}=\frac{C 1}{\mathrm{C} 2} \times 100
$$

2.7. Estimation of Proline Content. Proline is a part of the socalled osmoprotective molecules because they have a protective role at the level of proteins, protein complexes, and membranes. The accumulation of proline in leaves, stems, and roots is considered one of the most common induced responses to stress, making it an excellent stress detector.

Leaf samples from date palm seedlings were collected for the experiment. Extraction procedure and colorimetric determination were carried out as follows [40]: samples of $1 \mathrm{~g}$ leaf fresh weight were ground in a mortar after the addition of a small amount of quartz sand and $10 \mathrm{~mL}$ of a $3 \%(w / v)$ aqueous sulfosalicylic acid solution. The homogenate was filtered through two layers of Whatman filter paper. Two millilitres of filtrate was reacted with $2 \mathrm{ml}$ acid ninhydrin and $2 \mathrm{ml}$ of glacial acetic acid in a test tube for 1 hour at $100^{\circ} \mathrm{C}$, and the reaction was terminated in an ice bath. Readings were taken immediately at a wavelength of $546 \mathrm{~nm}$. The proline concentration was determined from a standard curve and calculated on a fresh weight basis $\left(\mu \mathrm{mol}\right.$ proline $\left.(\mathrm{g} \mathrm{FW})^{-1}\right)$.

\subsection{Estimation of Peroxidase}

2.8.1. Preparation of Enzyme Extracts. As previously mentioned, the enzyme extracts used were prepared at the same time as the protein extract and following the same method. Therefore, after being immediately frozen in liquid nitrogen and stored at $-25^{\circ} \mathrm{C}$, the samples were ground, centrifuged, and then used for the assays of enzymatic activities and total protein determination. 
2.8.2. Peroxidase. Tetraguaiacol absorbs at 436 or $470 \mathrm{~nm}$, unlike guaiacol $\left(\mathrm{E} 436=25.5 \mathrm{~L} \cdot \mathrm{mM}^{-1} \cdot \mathrm{cm}^{-1}\right.$ or $\left.\mathrm{E} 470=26.6 \mathrm{~L} \cdot \mathrm{mM}^{-1} \cdot \mathrm{cm}^{-1}\right)$. The reaction was carried out in $50 \mathrm{mM}$ potassium phosphate buffer $\mathrm{pH} 7.0$ containing $0.25 \mathrm{mM}$ of $5 \mathrm{mM} \mathrm{H}_{2} \mathrm{O}_{2}$ of guaiacol. The peroxidase activity was measured in a reaction medium containing $1 \mathrm{ml}$ of the phosphate buffer $50 \mathrm{mM}$ (pH 7), $5 \mathrm{mM}$ guaiacol, and $50 \mu \mathrm{l}$ of $5 \mathrm{mM} \mathrm{H} \mathrm{H}_{2} \mathrm{O}_{2}$ according to the method of Lin and Kao [41]. The kinetic evolution of the absorbance at $470 \mathrm{~nm}$ was measured for $1 \mathrm{~min}$. The speed of the reaction was recorded after adding a volume $v(\mu \mathrm{l})$ of the sample at $470 \mathrm{~nm}$, and the initial speed $V_{i}$ was measured in $\mathrm{D}_{\mathrm{O}} / \mathrm{min}$.

2.9. Estimation of Catalase. The hydrogen peroxide absorbs at $240 \mathrm{~nm}\left(\mathrm{E} 240=39.4 \mathrm{~L} \cdot \mathrm{mM}^{-1} \cdot \mathrm{cm}^{-1}\right)$, and therefore, its transformation in the presence of catalase will be followed by a reduction of the absorbance over time at this wavelength.

Catalase (CAT) activity was assayed spectrophotometrically by monitoring the decrease in absorbance of $\mathrm{H}_{2} \mathrm{O}_{2}$ at $240 \mathrm{~nm}$. CAT was measured according to the method of Brennan and Frenkel [42]. The reaction mixture consisted of $0.5 \mathrm{ml}$ of protein extract $(0.1 \mathrm{mg}$ total protein $/ \mathrm{ml})$ in $1 \mathrm{ml}$ of $50 \mathrm{mM}$ potassium phosphate buffer $(\mathrm{pH}$ 7.0) containing $20 \mathrm{mM} \mathrm{H} \mathrm{O}_{2}$. The reaction speed is recorded after adding a sample volume at $240 \mathrm{~nm}$, and the initial speed $V_{i}$ is measured in $\mathrm{D}_{\mathrm{O}} / \mathrm{min}$.

2.10. Estimation of SOD. Superoxide dismutase (SOD) includes a transition metal $(\mathrm{Fe}, \mathrm{Mn}$, or $\mathrm{Cu})$ at their active site. In the dismutation reaction, the metal ion picks up an electron from the superoxide anion and transfers it to the imidazole nucleus from one of the histidines at the active site.

The SOD activity was determined according to the method of Beyer and Fridovich [43], which was measured using spectrophotometry at $560 \mathrm{~nm}$ and by monitoring the inhibition of the photochemical reduction of the nitro blue tetrazolium (NBT) by the superoxide anion produced following the photoreaction of oxygen and riboflavin in the presence of an electron donor such as methionine. One unit of SOD activity was defined as the amount of enzyme required for $50 \%$ inhibition of the reduction rate of NBT. The reaction mixture consisted of $2.2 \mathrm{ml}$ of phosphate buffer (0.1 M, pH 7.8), $0.25 \mathrm{ml}$ of methionine $(13 \mathrm{mM}), 0.25 \mathrm{ml}$ of riboflavin $(1.2 \mu \mathrm{M}), 0.25 \mathrm{ml}$ of $\mathrm{NBT}(63 \mu \mathrm{M})$, and $50 \mu \mathrm{l}$ of the extract. The reaction was carried out at $25^{\circ} \mathrm{C}$ under a light intensity of 500 watts for $15 \mathrm{~min}$. The reaction was then stopped by placing the patch in the dark and at $4^{\circ} \mathrm{C}$ for about $10 \mathrm{~min}$, and then the absorbance was read with a spectrophotometer. A control was made and placed directly in the dark. The maximum photochemical reduction of NBT, Amax, is determined from the tubes exposed to light and containing the reaction mixture without enzymatic extract. The percentage inhibition of the photochemical reaction of NBT by SODs was calculated as follows:

$$
\begin{aligned}
\text { SOD } & =(\% \text { inh } / 50) /(\text { Cprot } \times V e), \\
\text { with } \% \text { inh } & =[(\mathrm{Ae} / \mathrm{Ac}) \times 100],
\end{aligned}
$$

where Cprot is the protein concentration obtained by the Bradford method ( $\mathrm{mg} / \mathrm{ml}), \mathrm{Ve}$ is the volume of the extract, $\%$ inh is the percentage inhibition of the formazan formation reaction, Ae is the absorbance of the extract (Abs light - Abs dark), and Ac is the absorbance of control.

2.11. Estimation of Glutathione S-Transferase. Glutathione S-transferase activity is determined based on a continuous spectrophotometric rate determination as previously reported by Habig et al. [44].

Enzyme activity with aromatic substrates was usually determined by monitoring changes in absorbance with a spectrophotometer. A complete assay mixture without enzyme was used as a control. Assays were conducted by mixing CDNB $1 \mathrm{mM}$ and GSH $5 \mathrm{mM}$ prepared solutions with the enzymatic extract. The absorbance reading was conducted every $1 \mathrm{~min}$ for $5 \mathrm{~min}$ at a wavelength of $340 \mathrm{~nm}$.

2.12. Experimental Design and Statistical Analysis. The experimental design was conducted in a greenhouse experiment design as a complete-block design with four field capacity levels consisting of four treatments (C: control plants; M: plants inoculated with mycorrhizal fungi; $M+B$ : plants inoculated with mycorrhizal fungi and PGPR bacteria; and B: plants inoculated with PGPR bacteria only) with 10 plants in each treatment. All measurements were done in triplicate. Data analysis was carried out by a two-way analysis of variance (ANOVA) followed by Tukey's post hoc tests to evaluate significant differences among the samples at a 95\% confidence interval using the SPSS computer program, version 20. 0 . The level of significance was $p<0.05$.

\section{Results}

3.1. The Plant Water Status. Severe water stress conditions (25\% and 50\% FC) negatively influenced the RWC (Figure 1(a)) and EC in the plants (Figure 1(b)). RWC significantly $(p<0.05)$ decreased under $25 \%$ FC compared with the $100 \%$ FC (by 55\% for the control treatment). The same decrease (by $32 \%$ for the control treatment) was obtained regarding membrane permeability of the plants. AMF and PGPR inoculation resulted in an increase of the RWC and EC parameters of date palm plants compared with the noninoculated plants (Figure 1) under normal conditions (100\% and $75 \%$ FC). Under severe water stress conditions (25\% and 50\% FC), RWC and EC increased in all inoculated AMF and PGPR treatments in comparison with noninoculated plants. Mycorrhizae plants have reached the highest RWC value in severe water stress (25\% FC) compared with all the other treatments.

3.2. Mycorrhizal Inoculation. The arbuscular mycorrhizal fungi successfully colonized all the mycorrhizal plants and developed typical intraradical structures such as arbuscules, vesicles, and hyphae. The frequency of colonization $(\mathrm{Fa} \%)$ reached a value of $96.67 \% \pm 5.774$ for the mycorrhizae $(\mathrm{M})$ and a value of $86.67 \pm 5.774$ for the mycorrhizae + bacteria 


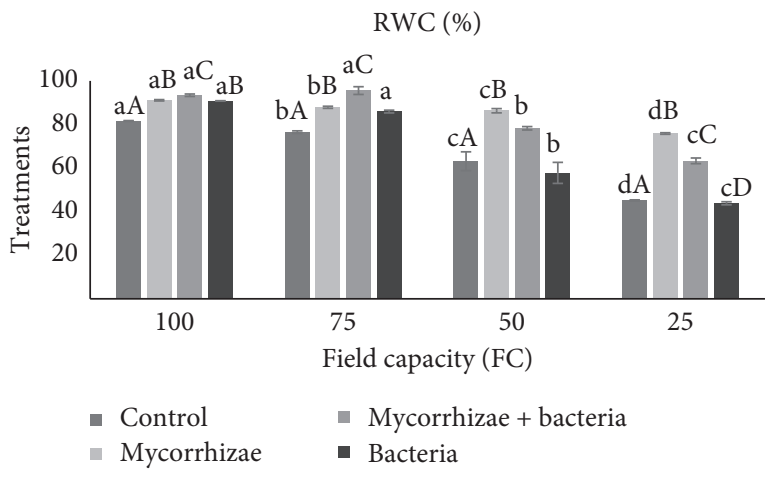

(a)

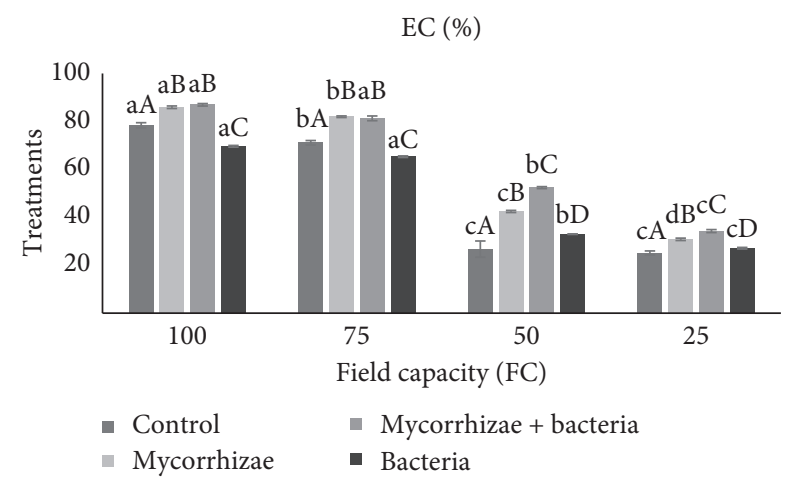

(b)

FIGURE 1: Effect of different water regimes on the water parameters ((a) RWC and (b) EC) of control, mycorrhizae, mycorrhizae + bacteria, and bacteria date palm seedlings after 8 months of growth. Lowercase letters in the same column indicate significant differences between FC at the same treatments $(p<0.05)$. Uppercase letters in the same column indicate significant differences between treatments at the same FC $(p<0.05)$.

$(\mathrm{M}+\mathrm{B})$ treatment in a normal water regime $(100 \% \mathrm{FC})$ (Figure 2). The results were more satisfying in the severe water stress regime of $25 \%$ FC. Fa\% reached a value of $76.67 \% \pm 5.774$ and $90.00 \% \pm 10.00$ for $\mathrm{M}$ and $\mathrm{M}+\mathrm{B}$ treatments, respectively (Figure 2). As for the intensity (Ia\%) of both $M$ and $M+B$ treatments, it increased significantly $(p<0.005)$ when the soil water deficiency increased, with a value of $81.67 \% \pm 1.528$ and $95.00 \% \pm 0.000$ in $25 \% \mathrm{FC}$ for both treatments, respectively (Figure 3 ). The mycorrhizae + bacteria showed very high values for both $\mathrm{Fa} \%$ and $\mathrm{Ia} \%$ of colonization compared with $\mathrm{M}$ treatment regardless of the water stress regime.

3.3. Proline. The proline content significantly increased under severe water stress conditions (25\% and 50\% FC) compared with well-watered conditions (100\% and $75 \%$ FC) regardless of the treatments applied (Figure 4). However, the results also indicated that single inoculation either with the AMF species or with PGPR significantly increased the proline content of date palm seedlings compared with the control plants in severe water stress conditions. The maximum proline content was obtained in plants inoculated with the AMF species and PGPR (combined) under severe water stress conditions (25\% and 50\% FC) reaching a value of $2.588 \pm 0.034$ in $25 \%$ FC compared with $0.978 \pm 0.024$ for the control. In normal irrigation conditions (100\% and $75 \% \mathrm{FC})$, there is no significant effect on the proline accumulation with the application of the mycorrhizal and bacterial treatment compared with the control.

3.3.1. Antioxidant Enzyme Activities. The SOD activity in plants leaves significantly $(p<0.01)$ increased under severe water stress conditions ( $25 \%$ and $50 \% \mathrm{FC}$ ) compared with well-watered conditions (100\% and $75 \%$ FC) (by 208\%) (Figure 5(a)). Furthermore, bacteria inoculated plants demonstrated a higher SOD activity with a maximum value of $203,985 \pm 14,042$ in severe water stress conditions (25\%) compared with the control. However, the results showed a

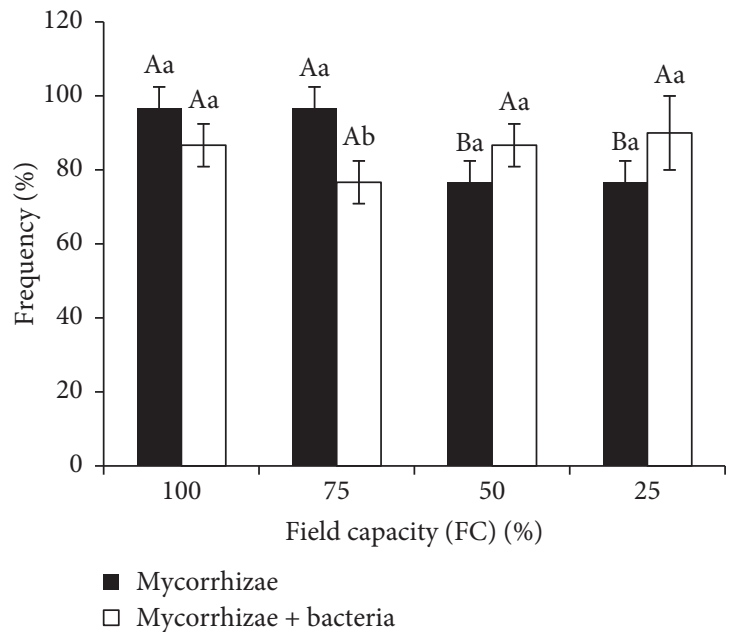

Figure 2: The frequency of colonization in mycorrhizae and mycorrhizae + bacteria plants under water deficit conditions. Vertical bars represent the standard deviation $(n=3)$. Bars with different lowercase letters indicate significant differences between treatments at the same FC $(p<0.05)$. Bars with different uppercase letters indicate significant differences in the same treatment at different FC percentages $(p<0.05)$.

decrease in the SOD activity with the application of mycorrhizae alone or combined with PGPR in severe water stress conditions compared with the control plants.

An elevated leaf CAT activity was observed in date palm plants under severe water stress conditions (25\% and 50\% FC) compared with well-watered conditions (100\% and $75 \%$ FC) (by 208\%) (Figure 5(b)). The mycorrhizae and mycorrhizae + bacteria treatments showed a decrease in leaf CAT activity during water stress conditions, and the mycorrhizae plants had lower leaf CAT activity than that of all the other treatments applied during the same conditions. The same pattern was observed for the leaf POX activity (Figure 5(c)), while it increased with the application of severe water stress conditions in all of the treatments, it decreased with the application of mycorrhizae, 


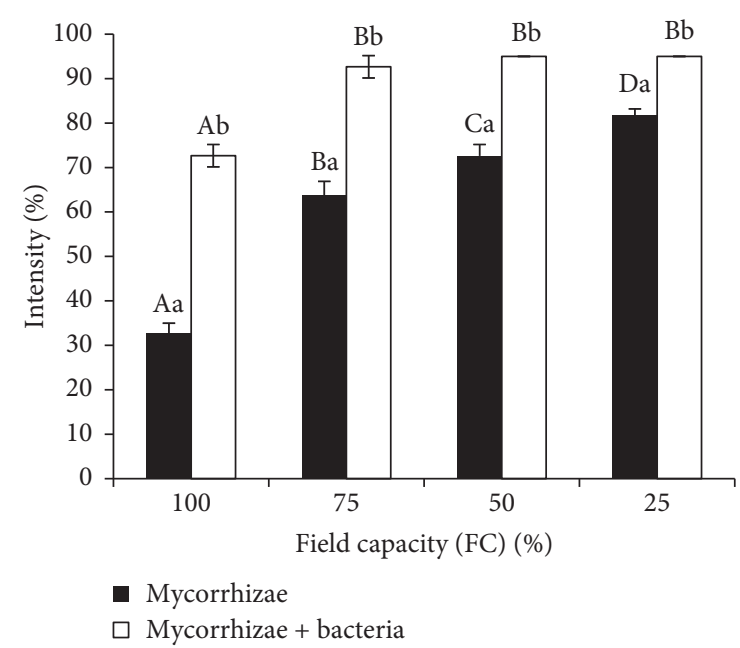

FIgURE 3: The intensity of colonization in mycorrhizae and mycorrhizae + bacteria plants under water deficit conditions. Vertical bars represent the standard deviation $(n=3)$. Bars with different lowercase letters indicate significant differences between treatments at the same FC $(p<0.05)$. Bars with different uppercase letters indicate significant differences in the same treatment at different FC percentages $(p<0.05)$.

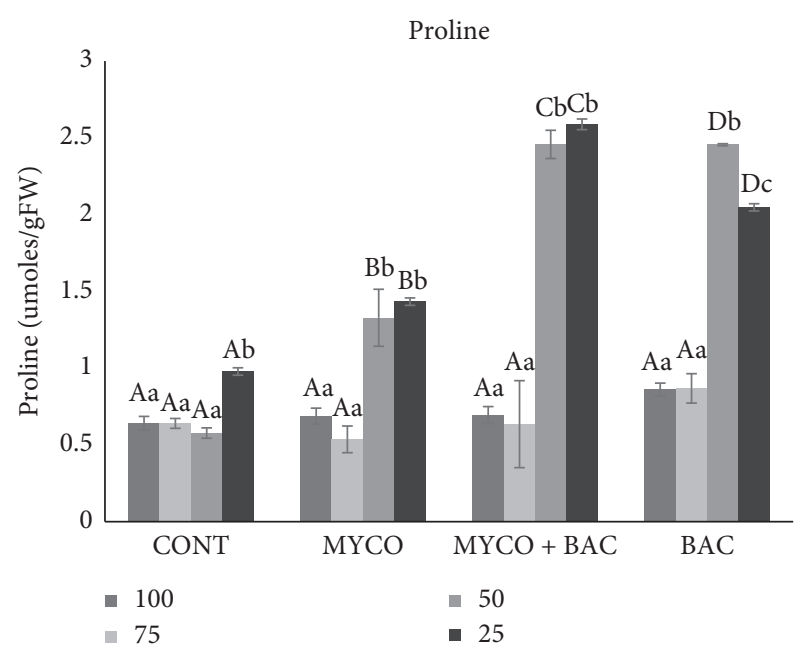

Figure 4: Effect of different water regimes (100\%, 75\%, 50\%, and $25 \%$ FC) and mycorrhizal and bacterial inoculation on proline concentration of date palm after 8 months of growth. Vertical bars represent the standard deviation $(n=3)$. CONT: control; MYCO: mycorrhizae. Bars with different lowercase letters indicate significant differences between FC at the same treatments $(p<0.05)$. Bars with different uppercase letters indicate significant differences between treatments at the same FC $(p<0.05)$.

mycorrhizae + bacteria, and bacteria treatment compared with the control and despite the application of the severe water stress conditions. The results showed an increase in the GST activity with the application of severe water stress regime in all of the treatments (Figure 5(d)). In the normal irrigation conditions, the GST activity increased with the application of mycorrhizae, mycorrhizae + bacteria, and bacteria treatments, while in stressful conditions, the GST activity decreased with the application of mycorrhizae, mycorrhizae + bacteria, and bacteria compared with the control.

\section{Discussion}

In general, date palm plants are expected to be droughttolerant, with a high yield potential under drought stress since they grow in arid and semiarid regions; however, actually, drought is a major limiting factor in date cultivation, making irrigation necessary, especially at an early stage of the plantation. Although these crops are known for their resistance to drought, their development is strongly impacted by variations in water availability and soil water content [29]. There are many agrophysiological parameters to evaluate drought stress in a plant (leaf area index, stomatal conductance, water potential, etc.) [45]. In this study, the leaf's relative water content (RWC) and the membrane permeability (EC) were used to evaluate the water status of the plants. The leaf's RWC is a significant predictor of water status in the plants since the balance between water supply to the leaf and transpiration rate can be more accurately expressed by the RWC's direct relation to cell volume [46]. The membrane permeability has long been considered a measure of the action of various stresses; it has often been used for screening against drought stress tolerance in different crops such as wheat [47], maize [48], and rice [49].

The parameters related to the plant's water status are represented in Figure 1. Leaf's RWC and membrane permeability (EC) were significantly $(p<0.05)$ higher in the plants treated with mycorrhizae and mycorrhizae + bacteria regardless of the water regime applied compared with their respective controls. In the same context, the application of severe water stress decreased the value of both leaf's RWC and EC regardless of the treatment of the plants, with the reduction being stronger in control plants than in the treated ones. Similar results were found by Faghire et al. [50] who reported that, with decreasing irrigation, RWC significantly decreased in nonmycorrhizal than in mycorrhizal seedlings. In fact, RWC was $4 \%$ higher in mycorrhizal seedlings than in nonmycorrhizal seedlings. Bacteria treatment only slightly improved the RWC in normal conditions (100\% and $75 \%$ FC) compared with the control; however, under stressful conditions, the bacterial inoculation did not enhance the RWC of the plants compared with the control. This could be due to the fact that bacteria did not interact directly with the plants but with another indirect mechanism, such as increasing root cell permeability by the bacteria for AMF colonization, thereby positively influencing the physiology of plants.

The positive effect of the mycorrhizal inoculation on the plant's water status that was shown in our results (Figure 1) could be explained by the creation of a mycorrhizal hyphal network that provides access to more nutrients and water to pass to the plants, thereby increasing their water absorption [51]. Furthermore, Jones [51] also mentioned that the absorptive region of mycorrhizal hyphae is about 100 times more efficient than root hair, which might justify the accessibility of more water for the plants and the high RWC value of the leaf. 


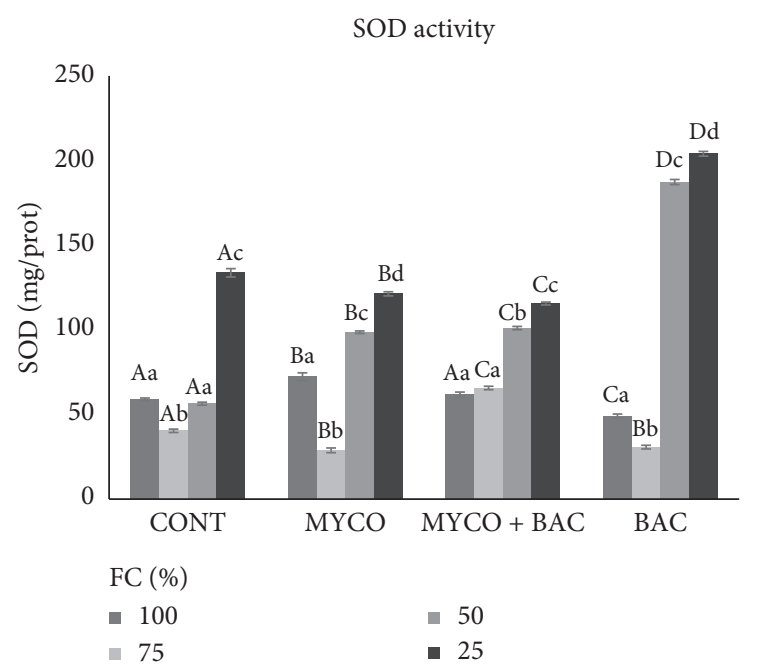

(a)

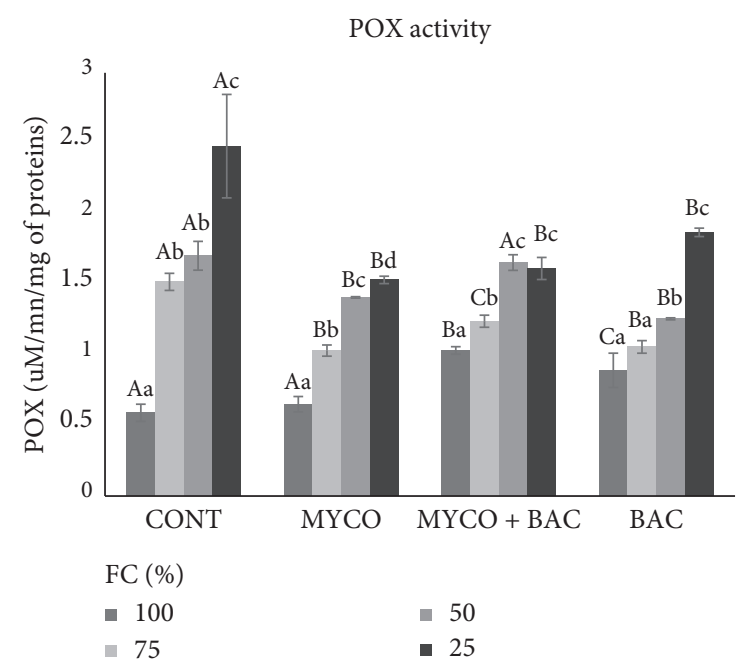

(c)

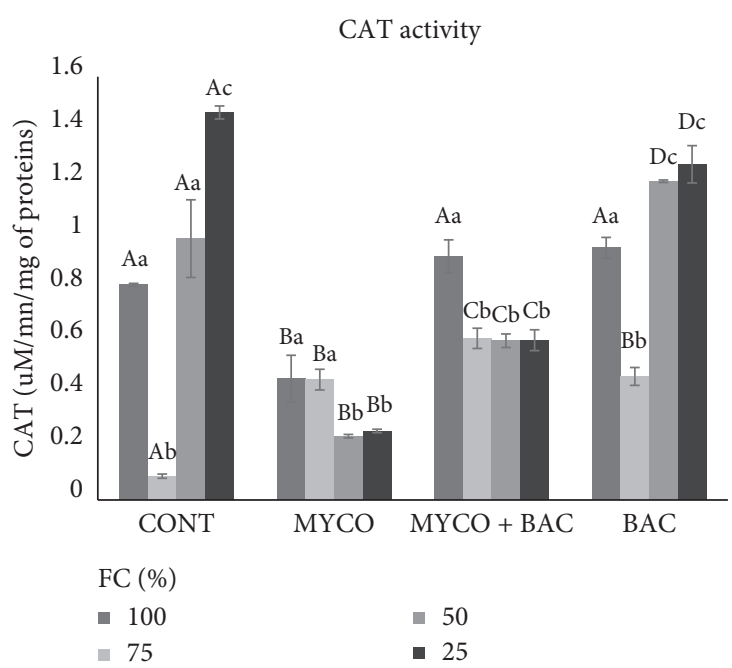

(b)

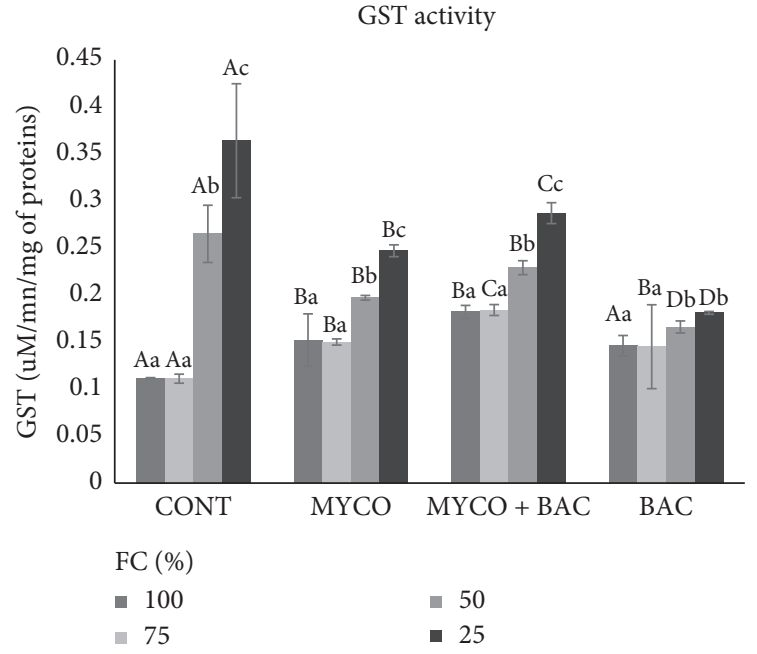

(d)

FIGURE 5: Enzyme activities of (a) superoxide dismutase (SOD; units.mg.protein.min ${ }^{-1}$ ), (b) catalase (CAT; $\mu$ M.mg ${ }^{-1} \cdot$ protein.min $^{-1}$ ), (c) peroxidase (POX; $\mu \mathrm{M} \cdot \mathrm{mg}^{-1}$.protein. $\mathrm{min}^{-1}$ ), and (d) glutathione S-transferase (GST; $\mu \mathrm{M} \cdot \mathrm{mg}^{-1} \cdot$ protein.min ${ }^{-1}$ ) in leaves of date palm seedlings (CONT: control; MYCO: mycorrhizae; MYCO + BAC: mycorrhizae + bacteria; BAC: bacteria) subjected to different field capacity (FC). Vertical bars represent the standard deviation $(n=3)$. Bars with different lowercase letters indicate significant differences between FC at the same treatments $(p<0.05)$. Bars with different uppercase letters indicate significant differences between treatments at the same FC $(p<0.05)$.

Several researchers have noticed that AMF can improve plant resistance to water deficiency [52-54], primarily due to the capacity of mycorrhizal roots to increase water conductivity [55]. There are opposed findings about the dual impact of AMF and PGPR inoculation on the plants [56-58]. However, some reports support the beneficial results obtained in the current study. For instance, Aalipour et al. [59] suggested that PGPR and AMF were successful in enhancing the activities of both communities in the rhizosphere. These synergistic relationships between PGPR and AMF can increase the plant water absorption and nutrient assimilation under water stress conditions and reduce the negative stress impacts on plant growth and development, which is demonstrated in this study using the mycorrhizal inoculation parameters (Figures 2 and 3). The complex of mycorrhizal fungi showed a good capacity to infect the roots of date palm plants in nonstressful conditions; infection parameters such as the frequency and intensity of these mycorrhizal fungi were hardly affected by the application of severe water stress (25\% FC).

Under stress conditions, especially drought and soil salinity, plant's proline is considered a fundamental osmoregulation solute. In fact, the accumulation of this amino acid may be a form of an adaptation to harsh environmental conditions, as reported by several researchers [14, 60-62]. In this study, leaf proline concentration was affected by both the severe water stress conditions and the treatment applied to the plants (mycorrhizae, mycorrhizae + bacteria, and bacteria) (Figure 4). When faced with oxidative stress, the best biochemical response of plant cells is the accumulation 
of osmolytes, like proline, in order to enhance osmosis and prevent dehydration. This explained the sudden increase of this molecule in our results (Figure 4). Comparable with our findings, an increase of proline accumulation in response to abiotic stress was reported in different studies [59, 63-66]. From these results, it can be concluded that the accumulation of proline under severe water stress conditions (Figure 4) was likely a general response of date palm to water stress conditions as an osmotic regulator. The proline content was higher in the dual inoculated plants than in separate inoculated plants. The mycorrhizal and bacterial inoculation may be the reason behind the proline accumulation in the leaves of the host plant. As a way of enhancing the defence mechanism of the plants, this inoculation increases the proline metabolism, thus a better osmotic adjustment [67]. Ortiz et al. [68] conducted a study on Trifoliumrepens plants inoculated with both PGPR bacteria and mycorrhizae under drought stress conditions. They showed that the greatest proline accumulation in shoots was found in plants dually inoculated with PGPR bacteria and mycorrhizae. Proline accumulation is a mechanism of resistance to abiotic stress by adjusting intracellular osmotic pressure. These results are in agreement with the works of Cherif [69] who reported that inoculation with Bacillus sp. and Pantoea agglomerans strain helped improve salt stress tolerance of wheat. This result does confer with ours under water stress conditions. Overall, the enhanced proline accumulation found in most dually inoculated plants resulted in a decrease in the osmotic cell potential, thereby increasing water absorption to preserve osmotic balance. It is a sign of the elevated osmoprotective potential and the ability to sustain the plant water status in inoculated plants under severe water stress conditions. It has been previously reported that proline can act as a chemical protein chaperone and prevent protein aggregation under water stress [70]. The enhancement of proline in plants treated with both AMF and PGPR helped to protect against oxidative stress compared with single inoculation since it is involved in the stabilization of redox enzymes. Also, this synergic relationship may be due to the bacterial effect on AM fungal germination, which leads to better mineral nutrition, facilitating the plant's growth promotion through the AM association. Anjum et al. [71] reported that the exogenous application of proline to cell cultures was positively correlated with the increased activity of different antioxidant enzymes (SOD, CAT, and POD enzymes) under water stress conditions. Some new insights into the regulation of plant immunity by amino acid metabolic pathways have been reported by Zeier. Hence, co-colonization by PGPR and AMF may lead to synergistic levels of immune priming in AMF-responsive plants. Moreover, when plants are under water stress conditions, inoculation with AMF and PGPR helps trigger proline gene expression and enzyme accumulation preventing cell death.

This study mainly focused on the oxidative responses of date palm seedlings inoculated with mycorrhizae and PGPR bacteria during water stress conditions. The results of the present study clearly showed the beneficial effects of AMF and PGPR bacteria inoculation in protecting plant cells.
However, plants tried to cope with the challenge through several mechanisms, such as the production or activation of antioxidant enzymes. The enzymes SOD, CAT, POX, and GST are among the main natural "detoxifiers" produced by the plants. They counteract the generation of the reactive oxygen species (ROS) and scavenge them in order to avoid the destruction of the cell membranes and oxidative damage inside the cells. These enzymes have been documented in many research works as a defence mechanism against biotic and abiotic stresses [1,72-75]. During normal conditions, the amount of ROS in the plant cells is kept under control by the antioxidant enzyme scavenging activity. However, this balance is disturbed in stressful conditions, causing the intracellular ROS levels to increase [76]. This leads to the application of new methods to help the plants cope with these imbalances. Numerous research works have highlighted the effect of mycorrhizae and PGPR bacteria on improving plant resistance, productivity, and metabolism under normal and stressful environments [77-83]. Therefore, to evaluate the effect of mycorrhizal and bacterial inoculation accurately during the application of different irrigation conditions $(100 \%, 75 \%, 50 \%$, and $25 \% \mathrm{FC})$, the enzymatic activity of SOD, CAT, POX, and GST was measured and is represented in Figures 5(a)-5(d). Contrary to Alguacil et al. [84] who found that, during water stress conditions, the Juniperusoxycedrus L. plants inoculated with AMF mixture expressed a higher SOD activity than noninoculated plants, Chang et al. [85] have reported that mycorrhizal Elaeagnus angustifolia L. seedlings had a higher leaf SOD activity than that of the nonmycorrhizal seedlings during salt stress conditions. The higher SOD activity expressed in the control and bacteria plants leads to the hypothesis that the noninoculated plants and plants with only bacterial inoculation were more sensitive to water stress than mycorrhizae or mycorrhizae + bacteria treatments. Therefore, they enhanced SOD activity earlier than the other treatments.

Drought stress caused a significant increase in the leaf CAT activity of the control and bacteria treatments (Figure 5(b)). From these findings, it can be concluded that the mycorrhizae and mycorrhizae + bacteria treatments decreased the leaf CAT activity in the date palm seedlings during severe water stress conditions. The same pattern was observed for the leaf POX activity (Figure 5(c)). Glutathione is the main category of antioxidants enzymes with a wide variety [86]. GST in plants plays an important role in the regulation of hormonal balance, herbicide detoxification, and plant senescence control in response to various abiotic stresses.

Considering the fact that $\mathrm{H}_{2} \mathrm{O}_{2}$ accumulation inside the plant cells triggers CAT and POX activity and that $\mathrm{H}_{2} \mathrm{O}_{2}$ is a product of SOD activity, a correlation between the activities of these enzymes can exist $[87,88]$. Low CAT and POX activity along with reduced SOD activity in both mycorrhizae and mycorrhizae + bacteria treatments than in control plants under severe water stress conditions can confirm that both mycorrhizal symbiosis and its combination with PGPR bacteria can alleviate plant oxidative stress. This agrees with previous results, in which Kohler et al. [89] found that 
Glomus intraradices, alone or in combination with Pseudomonas mendocina, caused a significant decrease in SOD activity in plants grown under drought conditions. This reduction in antioxidant enzymes can be interpreted in part by the fact that these plants could have been less sensitive to oxidative stress under water stress conditions. Otherwise, this is the first research to show the influence of both mycorrhizae and PGPR on POX, SOD, CAT, and GST activities of date palm plants grown under extreme drought conditions for "Najda" cultivar.

\section{Conclusion}

This study demonstrated the role played by the mycorrhizal and PGPR bacterial inoculations in reducing the damages of the oxidative stress in date palm plants at an enzymatic level. The results above supported that abiotic stress can negatively affect plant growth and development. However, this effect of stress on plant growth may be mitigated and/or reduced by the rhizosphere living microorganisms including bacteria and mycorrhizal fungi, applied individually or in combination. The enhanced resistance of the mycorrhizal fungi/ bacteria symbiosis in the date palm seedlings (Najda cultivar) during water stress conditions, in comparison with control plants, was affiliated with several biochemical characteristics such as better water absorption in normal and drought conditions, and improved the enzymatic response of the plants which improves the total health of the date palm plants. This can serve as a biological strategy for better crop production of plants exposed to severe water stress conditions, especially in arid and semiarid regions. Therefore, introducing the mycorrhizal and bacterial inoculations to these plantations can enhance the yield and production with less water consumption. However, since the experience was conducted under greenhouse conditions, it remains limited to a specific environment and leads towards a field experiment to better understand the effect of the biofertilization on date palm and its effect on the growth and the development of the plants.

\section{Data Availability}

The data used to support the findings of this study are included within the article.

\section{Conflicts of Interest}

The authors reported no potential conflicts of interest.

\section{Acknowledgments}

The authors are thankful to the National Institute of Agronomic Research Marrakech, Morocco, for cooperation during the experimental period.

\section{References}

[1] A. Shanker, Abiotic Stress Response in Plants - Physiological, Biochemical and Genetic Perspectives, InTech, London, UK, 2011.
[2] S. Hussain Wani, N. Brajendra Singh, A. Haribhushan, and J. Iqbal Mir, "Compatible solute engineering in plants for abiotic stress tolerance-role of Glycine betaine," Current Genomics, vol. 14, no. 3, pp. 157-165, 2013.

[3] P. Ahmad and M. N. V. Prasad, Abiotic Stress Responses in Plants: Metabolism, Productivity and Sustainability, Springer, New York, NY, USA, 2012.

[4] L. Cattivelli, F. Rizza, F.-W. Badeck et al., "Drought tolerance improvement in crop plants: an integrated view from breeding to genomics," Field Crops Research, vol. 105, no. 1-2, pp. 1-14, 2008.

[5] E. Epstein, J. D. Norlyn, D. W. Rush et al., "Saline culture of crops: a genetic approach," Science, vol. 210 , no. 4468, pp. 399-404, 1980.

[6] L. A. del Rio, L. M. Sandalio, D. A. Altomare, and B. A. Zilinskas, "Mitochondrial and peroxisomal manganese superoxide dismutase: differential expression during leaf senescence," Journal of Experimental Botany, vol. 54, no. 384, pp. 923-933, 2003.

[7] V. I. Lushchak, "Adaptive response to oxidative stress: bacteria, fungi, plants and animals," Comparative Biochemistry and Physiology Part C: Toxicology \& Pharmacology, vol. 153, no. 2, pp. 175-190, 2011.

[8] S. Gan and R. M. Amasino, "Making sense of senescence (molecular genetic regulation and manipulation of leaf senescence)," Plant Physiology, vol. 113, no. 2, pp. 313-319, 1997.

[9] A. Fusconi and G. Berta, "Environmental stress and role of arbuscular mycorrhizal symbiosis," in Abiotic Stress Responses in Plants, pp. 197-214, Springer, Berlin, Germany, 2012.

[10] G. Berg, "Plant-microbe interactions promoting plant growth and health: perspectives for controlled use of microorganisms in agriculture," Applied Microbiology and Biotechnology, vol. 84, no. 1, pp. 11-18, 2009.

[11] B. R. Glick, Z. Cheng, J. Czarny, and J. Duan, "Promotion of plant growth by ACC deaminase-producing soil bacteria," European Journal of Plant Pathology, vol. 119, no. 3, pp. 329-339, 2007.

[12] R. Hayat, S. Ali, U. Amara, R. Khalid, and I. Ahmed, "Soil beneficial bacteria and their role in plant growth promotion: a review," Annals of Microbiology, vol. 60, no. 4, pp. 579-598, 2010.

[13] B. R. Glick, "The enhancement of plant growth by free-living bacteria," Canadian Journal of Microbiology, vol. 41, no. 2, pp. 109-117, 1995.

[14] M. Ashraf, "Biotechnological approach of improving plant salt tolerance using antioxidants as markers," Biotechnology Advances, vol. 27, no. 1, pp. 84-93, 2009.

[15] B. Giri, R. Kapoor, and K. G. Mukerji, "Improved tolerance of Acacia nilotica to salt stress by arbuscular mycorrhiza, glomus fasciculatum may be partly related to elevated $\mathrm{K} / \mathrm{Na}$ ratios in root and shoot tissues," Microbial Ecology, vol. 54, no. 4, pp. 753-760, 2007.

[16] R. Kapoor, D. Sharma, and A. K. Bhatnagar, "Arbuscular mycorrhizae in micropropagation systems and their potential applications," Scientia Horticulturae, vol. 116, no. 3, pp. 227-239, 2008.

[17] H. Evelin, R. Kapoor, and B. Giri, "Arbuscular mycorrhizal fungi in alleviation of salt stress: a review," Annals of Botany, vol. 104, no. 7, pp. 1263-1280, 2009.

[18] M. Miransari, "Contribution of arbuscular mycorrhizal symbiosis to plant growth under different types of soil stress," Plant Biology, vol. 12, pp. 563-569, 2010. 
[19] A. Varma, R. Prasad, and N. Tuteja, Mycorrhiza-Nutrient Uptake, Biocontrol, Ecorestoration, Springer, Berlin, Germany, 2018.

[20] A. A. H. A. Latef, A. Hashem, S. Rasool et al., "Arbuscular mycorrhizal symbiosis and abiotic stress in plants: a review," Journal of Plant Biology, vol. 59, no. 5, pp. 407-426, 2016.

[21] M. M. Alguacil, J. A. Hernández, F. Caravaca, B. Portillo, and A. Roldán, "Antioxidant enzyme activities in shoots from three mycorrhizal shrub species afforested in a degraded semiarid soil," Physiologia Plantarum, vol. 118, no. 4, pp. 562-570, 2003.

[22] Q.-S. Wu and R.-X. Xia, "Arbuscular mycorrhizal fungi influence growth, osmotic adjustment and photosynthesis of citrus under well-watered and water stress conditions," Journal of Plant Physiology, vol. 163, no. 4, pp. 417-425, 2006.

[23] T. Khaosaad, J. M. García-Garrido, S. Steinkellner, and H. Vierheilig, "Take-all disease is systemically reduced in roots of mycorrhizal barley plants," Soil Biology and Biochemistry, vol. 39, no. 3, pp. 727-734, 2007.

[24] W. Schliemann, C. Ammer, and D. Strack, "Metabolite profiling of mycorrhizal roots of Medicago truncatula," Phytochemistry, vol. 69, no. 1, pp. 112-146, 2008.

[25] G. Selvakumar and P. Thamizhiniyan, "The effect of the arbuscular mycorrhizal (AM) fungus glomus intraradices on the growth and yield of chilli (capsicum annuum L.) under salinity stress," World Applied Sciences Journal, vol. 14, no. 8, pp. 1209-1214, 2011.

[26] P. Suprasanna, G. C. Nikalje, and A. N. Rai, "Osmolyte accumulation and implications in plant abiotic stress tolerance," in Osmolytes and Plants Acclimation to Changing Environment: Emerging Omics Technologies, N. Iqbal, R. Nazar, and N. A. Khan, Eds., Springer, New Delhi, India, pp. 1-12, 2016.

[27] C. T. Chao and R. R. Krueger, "The date palm (phoenix dactylifera L.): overview of biology, uses, and cultivation," HortScience, vol. 42, no. 5, pp. 1077-1082, 2007.

[28] M. H. Sedra, Le palmier dattier base de la mise en valeur des oasis au Maroc techniques phoénicicoles et création d'oasis, INRA Editions, Rabat, Morocco, 2003.

[29] M. Sedra, "Development of new Moroccan selected date palm varieties resistant to bayoud and of good fruit quality," in Date Palm Biotechnology, S. M. Jain, J. M. Al-Khayri, and D. V. Johnson, Eds., Springer, Dordrecht, Netherlands, pp. 513-531, 2011.

[30] L. Simova-Stoilova, K. Demirevska, T. Petrova, N. Tsenov, and U. Feller, "Antioxidative protection in wheat varieties under severe recoverable drought at seedling stag," Plant, Soil and Environment, vol. 54, no. No. 12, pp. 529-536, 2008.

[31] L. Chrouqi, L. Ouahmane, I. Jadrane, T. Koussa, and M. Al feddy, "Effects of plant growth promoting rhizobacteria (PGPRs) product IAA on the growth of two Moroccan wheat varieties (Triticum durum Desf.)," Research Journal of Pharmaceutical, Biological and Chemical Sciences, vol. 8, no. 3, p. 2296, 2017.

[32] A. Trouvelot, J. L. Kough, and V. Gianinazzi-Pearson, "Mesure du taux de mycorhization VA d'un systeme radiculaire. Recherche de methodes d'estimation ayant une signification fonctionnelle," Physiological and Genetical Aspects of Mycorrhizae, vol. 1, 1986.

[33] D. G. Strullu, B. Grellier, D. Marciniak, and R. Letouzé, "Micropropagation of chestnut and conditions of mycorrhizal syntheses in vitro," New Phytologist, vol. 102, no. 1, pp. 95-101, 1986.

[34] S. Mayak, T. Tirosh, and B. R. Glick, "Stimulation of the growth of tomato, pepper and mung bean plants by the plant growth- promoting BacteriumEnterobacter cloacaeCAL3," Biological Agriculture \& Horticulture, vol. 19, no. 3, pp. 261274, 2001.

[35] M. Dworkin and J. W. Foster, "Experiments with some microorganisms which utilize ethane and Hydrogen1," Journal of Bacteriology, vol. 75, no. 5, pp. 592-603, 1958.

[36] R. M. Tobar, R. Azcón, and J. M. Barea, "The improvement of plant $\mathrm{N}$ acquisition from an ammonium-treated, droughtstressed soil by the fungal symbiont in arbuscular mycorrhizae," Mycorrhiza, vol. 4, no. 3, pp. 105-108, 1994.

[37] J. M. Phillips and D. S. Hayman, "Improved procedures for clearing roots and staining parasitic vesicular-arbuscular mycorrhizal fungi for rapid assessment of infection," Transactions of the British Mycological Society, vol. 55, pp. 158-161, 1970.

[38] J. S. Boyer, "Experimental botany monographs," Science, vol. 158, no. 3805, pp. 1171-1172, 1967.

[39] B. Yan, Q. Dai, X. Liu, S. Huang, and Z. Wang, "Floodinginduced membrane damage, lipid oxidation and activated oxygen generation in corn leaves," Plant and Soil, vol. 179, no. 2, pp. 261-268, 1996.

[40] L. S. Bates, R. P. Waldren, and I. D. Teare, "Rapid determination of free proline for water-stress studies," Plant and Soil, vol. 39, no. 1, pp. 205-207, 1973.

[41] C. C. Lin and C. H. Kao, "NaCl induced changes in ionically bound peroxidase activity in roots of rice seedlings," Plant and Soil, vol. 216, no. 1/2, pp. 147-153, 1999.

[42] T. Brennan and C. Frenkel, "Involvement of Hydrogen Peroxide in the Regulation of Senescence in Pear," Plant Physiology, vol. 59, no. 3, pp. 411-416, 1977.

[43] W. F. Beyer and I. Fridovich, "Assaying for superoxide dismutase activity: Some large consequences of minor changes in conditions," Analytical Biochemistry, vol. 161, no. 2, pp. 559-566, 1987.

[44] H. W. Habig, J. M. Pabst, G. Fleischner, Z. Gatmaitan, M. I. Arias, and B. W. Jakoby, "The Identity of Glutathione S-Transferase B with Ligandin, a Major Binding Protein of Liver," Journal of Biological Chemistry, vol. 249, no. 22, pp. 71300-77139, 1974.

[45] M. d. A. Silva, J. L. Jifon, J. A. G. d. Silva, and V. Sharma, "Use of physiological parameters as fast tools to screen for drought tolerance in sugarcane," Brazilian Journal of Plant Physiology, vol. 19, no. 3, pp. 193-201, 2007.

[46] M. A. Schonfeld, R. C. Johnson, B. F. Carver, and D. W. Mornhinweg, "Water Relations in Winter Wheat as Drought Resistance Indicators," Crop Science, vol. 28, no. 3, pp. 526-531, 1988.

[47] I. ElBasyoni, M. Saadalla, S. Baenziger, H. Bockelman, and S. Morsy, "Cell membrane stability and association mapping for drought and heat tolerance in a worldwide wheat collection," Sustainability, vol. 9, no. 9, p. 1606, 2017.

[48] L.-P. Bai, F.-G. Sui, T.-D. Ge, Z.-H. Sun, Y.-Y. Lu, and G.-S. Zhou, "Effect of soil drought stress on leaf water status, membrane permeability and enzymatic antioxidant system of maize," Pedosphere, vol. 16, no. 3, pp. 326-332, 2006.

[49] J. N. Tripathy, J. Zhang, S. Robin, T. T. Nguyen, and H. T. Nguyen, "QTLs for cell-membrane stability mapped in rice (Oryza sativa L.) under drought stress," Theoretical and Applied Genetics, vol. 100, no. 8, pp. 1197-1202, 2000.

[50] M. Faghire, S. Samri, A. Meddich, M. Baslam, N. Goicoechea, and A. Qaddoury, "Positive effects of arbuscular mycorrhizal fungi on biomass production, nutrient status and water relations in date palm seedlings under water deficiency," Acta Horticulturae, vol. 882, no. 882, pp. 833-838, 2010. 
[51] C. Jones, "Mycorrhizal fungi-powerhouse of the Soil," The National Commission on Farmers, vol. 8, pp. 4-5, 2014.

[52] R. Amiri, A. Nikbakht, M. Rahimmalek, and H. Hosseini, "Variation in the essential oil composition, antioxidant capacity, and physiological characteristics of pelargonium graveolens L. inoculated with two species of mycorrhizal fungi under water deficit conditions," Journal of Plant Growth Regulation, vol. 36, no. 2, pp. 502-515, 2017.

[53] S. Rahimzadeh and A. Pirzad, "Arbuscular mycorrhizal fungi and Pseudomonas in reduce drought stress damage in flax (Linum usitatissimum L.): a field study," Mycorrhiza, vol. 27, no. 6, pp. 537-552, 2017.

[54] Z. Moradi Tarnabi, A. Iranbakhsh, I. Mehregan, and R. Ahmadvand, "Impact of arbuscular mycorrhizal fungi (AMF) on gene expression of some cell wall and membrane elements of wheat (Triticum aestivum L.) under water deficit using transcriptome analysis," Physiology and Molecular Biology of Plants, vol. 26, no. 1, pp. 143-162, 2020.

[55] J. A. Siemens and J. J. Zwiazek, "Changes in root water flow properties of solution culture-grown trembling aspen (Populus tremuloides) seedlings under different intensities of water-deficit stress," Physiologia Plantarum, vol. 121, no. 1, pp. 44-49, 2004.

[56] M. Hassan, J. McInroy, and J. Kloepper, "The interactions of rhizodeposits with plant growth-promoting rhizobacteria in the rhizosphere: a review," Agriculture, vol. 9, no. 7, p. 142, 2019.

[57] T. Yasmeen, M. Tariq, S. Iqbal et al., "Ameliorative capability of plant growth promoting rhizobacteria (PGPR) and arbuscular mycorrhizal fungi (AMF) against salt stress in plant," in Plant Abiotic Stress Tolerance: Agronomic, Molecular and Biotechnological Approaches, M. Hasanuzzaman, K. R. Hakeem, K. Nahar, and H. F. Alharby, Eds., Springer International Publishing, Cham, Switzerland, pp. 409-448, 2019.

[58] J. Pan, F. Peng, X. Xue et al., "The growth promotion of two salt-tolerant plant groups with pgpr inoculation: a metaanalysis," Sustainability, vol. 11, no. 2, p. 378, 2019.

[59] H. Aalipour, A. Nikbakht, N. Etemadi, F. Rejali, and M. Soleimani, "Biochemical response and interactions between arbuscular mycorrhizal fungi and plant growth promoting rhizobacteria during establishment and stimulating growth of Arizona cypress (Cupressus arizonica G.) under drought stress," Scientia Horticulturae, vol. 261, Article ID 108923, 2020.

[60] H. Abbaspour, S. Saeidi-Sar, and H. Afshari, "Improving drought tolerance of Pistacia vera L. seedlings by arbuscular mycorrhiza under greenhouse conditions," Journal of $\mathrm{Me}$ dicinal Plant Research, vol. 5, no. 32, pp. 7065-7072, 2011.

[61] S. Hayat, Q. Hayat, M. N. Alyemeni, A. S. Wani, J. Pichtel, and A. Ahmad, "Role of proline under changing environments," Plant Signaling \& Behavior, vol. 7, no. 11, pp. 1456-1466, 2012.

[62] X. Liang, L. Zhang, S. K. Natarajan, and D. F. Becker, "Proline Mechanisms of Stress Survival," Antioxidants \& Redox Signaling, vol. 19, no. 9, pp. 998-1011, 2013.

[63] M. A. Hoque, N. A. Banu, Y. Nakamura, Y. Shimoishi, and Y. Murata, "Proline and glycinebetaine enhance antioxidant defense and methylglyoxal detoxification systems and reduce $\mathrm{NaCl}$-induced damage in cultured tobacco cells," Journal of Plant Physiology, vol. 165, no. 8, pp. 813-824, 2008.

[64] M. W. Yaish, "Short Communication Proline accumulation is a general response to abiotic stress in the date palm tree (Phoenix dactylifera L.)," Genetics and Molecular Research, vol. 14, no. 3, pp. 9943-9950, 2015.
[65] M. Zouari, C. Ben Ahmed, W. Zorrig et al., "Exogenous proline mediates alleviation of cadmium stress by promoting photosynthetic activity, water status and antioxidative enzymes activities of young date palm (Phoenix dactylifera L.)," Ecotoxicology and Environmental Safety, vol. 128, pp. 100-108, 2016.

[66] A. M. W. Al-Mayahi, "Effect of aluminum on the growth of the in vitro culture tissues of the date palm (Phoenix dactylifera L.) cv. Um-Aldehin," Folia Oecologica, vol. 46, no. 2, pp. 164-169, 2019.

[67] J. M. Ruiz-Lozano, R. Azcon, and M. Gomez, "Effects of arbuscular-mycorrhizal glomus species on drought tolerance: physiological and nutritional plant responses," Applied and Environmental Microbiology, vol. 61, no. 2, pp. 456-460, 1995.

[68] N. Ortiz, E. Armada, E. Duque, A. Roldán, and R. Azcón, "Contribution of arbuscular mycorrhizal fungi and/or bacteria to enhancing plant drought tolerance under natural soil conditions: Effectiveness of autochthonous or allochthonous strains," Journal of Plant Physiology, vol. 174, pp. 87-96, 2015.

[69] H. Cherif, Amélioration de la croissance du blé dur en milieu salin par inoculation avec Bacillus sp. et Pantoea agglomerans isolées de sols arides, Université Ferhat Abbas Sétif, Sétif, Algeria, 2014.

[70] Z. Ignatova and L. M. Gierasch, "Inhibition of protein aggregation in vitro and in vivo by a natural osmoprotectant," Proceedings of the National Academy of Sciences, vol. 103, no. 36, pp. 13357-13361, 2006.

[71] S. A. Anjum, U. Ashraf, M. Tanveer et al., "Drought induced changes in growth, osmolyte accumulation and antioxidant metabolism of three maize hybrids," Frontiers in Plant Science, vol. 8, 2017.

[72] S. Toscano, A. Ferrante, and D. Romano, "Response of Mediterranean Ornamental Plants to Drought Stress," Horticulturae, vol. 5, no. 1, p. 6, 2019.

[73] S. Rasool, B. A. Mir, M. U. Rehman, I. Amin, M. U. R. Mir, and S. B. Ahmad, "Abiotic stress and plant senescence," in Senescence Signalling and Control in Plants 27 pages, Elsevier, Amsterdam, Netherlands, 2019.

[74] A. Khan, X. Pan, U. Najeeb et al., "Coping with drought: stress and adaptive mechanisms, and management through cultural and molecular alternatives in cotton as vital constituents for plant stress resilience and fitness," Biological Research, vol. 51, no. 1, p. 47, 2018.

[75] I. M. Sakran, H. A. E. Rabey, Y. Q. Almulaiky, M. A. Al-Duais, M. Elbakry, and U. Faridi, "The antioxidant enzymatic activity of date palm seedlings under abiotic drought stress," Indian Journal of Pharmaceutical Education and Research, vol. 52, no. 3, pp. 442-448, 2018.

[76] S. Bhattacharjee, "Reactive oxygen species and oxidative burst: Roles in stress, senescence and signal transduction in plants Current Science," Current Science, vol. 89, no. 7, 2005.

[77] P. Jeffries, S. Gianinazzi, S. Perotto, K. Turnau, and J.-M. Barea, "the contribution of arbuscular mycorrhizal fungiin sustainable maintenance of plant health and soil fertility," Biology and Fertility of Soils, vol. 37, pp. 1-16, 2002.

[78] J. A. López-Ráez and M. J. Pozo, "Chemical signalling in the arbuscular mycorrhizal symbiosis: biotechnological applications," Soil Biology, Symbiotic Endophytes, vol. 37, pp. 215232, 2013.

[79] A. Abdel Latef, "Growth and some physiological activities of pepper (Capsicum annuum L.) in response to cadmium stress and mycorrhizal symbiosysis," Journal of Agriculture, Science and Technology, vol. 15, pp. 1437-1448, 2013. 
[80] A. A. H. Abdel Latef and H. Chaoxing, "Does Inoculation with Glomus mosseae Improve Salt Tolerance in Pepper Plants?” Journal of Plant Growth Regulation, vol. 33, no. 3, pp. 644653, 2014.

[81] S. R. Vimal, J. S. Singh, N. K. Arora, and S. Singh, "Soil-plantmicrobe interactions in stressed agriculture management: a review," Pedosphere, vol. 27, no. 2, pp. 177-192, 2017.

[82] D. Mbodj, B. Effa-Effa, A. Kane et al., "Arbuscular mycorrhizal symbiosis in rice: Establishment, environmental control and impact on plant growth and resistance to abiotic stresses," Rhizosphere, vol. 8, pp. 12-26, 2018.

[83] A. Askari, M. R. Ardakani, F. Paknejad, and Y. Hosseini, "Effects of mycorrhizal symbiosis and seed priming on yield and water use efficiency of sesame under drought stress condition," Scientia Horticulturae, vol. 257, pp. 108749109205, 2019.

[84] M. Alguacil, F. Caravaca, P. Díaz-Vivancos, J. A. Hernández, and A. Roldán, "Effect of arbuscular mycorrhizae and induced drought stress on antioxidant enzyme and nitrate reductase activities in juniperus oxycedrus l. grown in a composted sewage sludge-amended semi-arid soil," Plant and Soil, vol. 279, no. 1-2, pp. 209-218, 2006.

[85] W. Chang, X. Sui, X.-X. Fan, T.-T. Jia, and F.-Q. Song, "Arbuscular mycorrhizal symbiosis modulates antioxidant response and ion distribution in salt-stressed elaeagnus angustifolia seedlings," Frontiers in Microbiology, vol. 9, p. $652,2018$.

[86] R. A. Dixon, L. Achnine, P. Kota, C.-J. Liu, M. S. S. Reddy, and L. Wang, "The phenylpropanoid pathway and plant defence-a genomics perspective," Molecular Plant Pathology, vol. 3, no. 5, pp. 371-390, 2002.

[87] M. J. Droillard, A. Paulin, and J. C. Massot, "Free radical production, catalase and superoxide dismutase activities and membrane integrity during senescence of petals of cut carnations (Dianthus caryophyllus)," Physiologia Plantarum, vol. 71, no. 2, pp. 197-202, 1987.

[88] D. Lacan and J.-C. Baccou, "High levels of antioxidant enzymes correlate with delayed senescence in nonnetted muskmelon fruits," Planta, vol. 204, no. 3, pp. 377-382, 1998.

[89] J. Kohler, J. A. Hernández, F. Caravaca, and A. Roldán, "Plantgrowth-promoting rhizobacteria and arbuscular mycorrhizal fungi modify alleviation biochemical mechanisms in waterstressed plants," Functional Plant Biology, vol. 35, no. 2, p. 141, 2008. 